\title{
PENGARUH PENERIMAAN PAJAK DAERAH DAN RETRIBUSI DAERAH, TERHADAP PENINGKATAN PENDAPATAN ASLI DAERAH (PAD) \\ (Studi Empiris Pada Kabupaten/Kota Provinsi Sumatera Utara Periode 2017-2020)
}

\author{
Kornelius Harefa ${ }^{1}$, Khairunisa Tampubolon ${ }^{2}$ \\ Universitas Negeri Medan ${ }^{1,2}$ \\ korneliusharefa@unimed.ac.id ${ }^{1}$
}

\begin{abstract}
Abstrak
Permasalahan dalam penelitian ini adalah apakah pajak daerah dan retribusi daerah berpengaruh terhadap pendapatan asli daerah pada pemerintahan Kabupaten/Kota Sumatera Utara. Penelitian ini bertujuan untuk mengetahui pengaruh pajak daerah dan retribusi daerah terhadap pendapatan asli daerah pada pemerintahan Kabupaten/Kota Sumatera Utara. Data yang digunakan dalam penelitian ini adalah data sekunder yaitu Laporan Realisasi Anggaran Pendapatan dan Belanja Daerah (APBD) Kabupaten/Kota Provinsi Sumatera Utara tahun 2016-2018. Populasi dalam penelitian ini adalah seluruh kabupaten/kota di Provinsi Sumatera Utara yang terdiri dari 33 kabupaten (25 Kabupaten dan 5 kota). Metode yang digunakan dalam penentuan sampling adalah Saturated Sampling (sampling jenuh). Penelitian ini menggunakan analisis regresi berganda dengan SPSS Versi 20. Kesimpulan dari penelitian ini menunjukkan Pajak Daerah berpengaruh terhadap Pendapatan Asli Daerah. Sementara Retribusi Daerah tidak berpengaruh terhadap Pendapatan Asli Daerah.
\end{abstract}

Kata Kunci: Pajak Daerah, Retribusi Daerah, Pendapatan Asli Daerah 


\section{Pendahuluan}

Undang-Undang Nomor 23 Tahun 2014 tentang Pemerintah Daerah. Menjelaskan bahwa Wujud dari kebijakan desentralisasi adalah lahimya otonomi daerah. Dari undang-undang tersebut Pemerintah pusat menerapkan kebijakan dimana pemerintah daerah diberikan kewenangan untuk mengelola keuangan daerahnya masing-masing, suatu proses yang dikenal dengan desentralisasi, dengan harapan daerah dapat mendanai pembangunan daerahnya sendiri sesuai dengan prinsip daerah otonom yang nyata.

Sebagaimana yang dijelaskan dalam Undang-Undang Nomor 32 Tahun 2004 tentang Pemerintah Daerah. Munculnya Undang-Undang Nomor 12 Tahun 2008 tentang perubahan kedua atas UndangUndang Nomor 32 Tahun 2004 tentang Pemerintahan Daerah membawa perubahan yang begitu besar bagi pelaksanaan pembangunan daerah. Secara tegas undang-undang ini memberikan kewenangan kepada daerah untuk mengatur dan mengurus kepentingan masyarakat setempat.

Dalam pelaksanaan Otonomi Daerah dimana peranan Pendapatan asli daerah diaharapkan dan diupayakan dapat menjadi penyangga utama dalam membiayai kegiatan pembangunan di daerah. Sumber-sumber penerimaan daerah dalam rangka pelaksanaan desentralisasi adalah sebagai berikut: (1) Pendapatan asli Daerah, (2) Pinjaman Daerah, (3) Dana Perimbangan, (4) Lain-lain Penerimaan sah. Sedangkan Pendapatan Asli Daerah terdiri dari 4 komponen yaitu: (1) Pajak Daerah, (2) Retribusi Daerah, (3) hasil pengelolaan kekayaan daerah yang dipisahkan, (4) dan lain-lain pendapatan daerah yang sah.

Pajak daerah merupakan sumber pendapatan asli daerah yang memiliki kontribusi sangat penting dalam membiayai pemerintahan serta pembangunan daerah karena pajak daerah bermanfaat dalam meningkatkan kemampuan penerimaan Pendapatan Asli Daerah serta mendorong laju pertumbuhan ekonomi daerah. Uang pajak dipergunakan untuk belanja pegawai hingga pembiayaan berbagai proyek pembangunan. Pembangunan sarana umum seperti jalan, jembatan, rumah sakit/puskesmas, sekolah dan kantor polisi semuanya dibiayai dengan menggunakan uang yang berasal dari penerimaan pajak.

Retribusi daerah adalah pungutan daerah sebagai pembayaran atas jasa atau pemberian izin tertentu dari pemerintah daerah kepada perseorangan maupun badan. Retribusi mengacu pada pungutan dari daerah yang dikenakan hanya kepada pihak yang diberikan jasa tertentu atau izin khusus untuk mengelola kekayaan daerah. Hal tersebut tentu berbeda dengan pajak yang diatur secara langsung oleh pemerintah dan dikenakan secara menyeluruh kepada masyarakat.

Sejak otonomi daerah, setiap daerah berusaha menggali potensi keuangan daerah melalui PAD. Dengan dilakukannya hal tersebut seharusnya pendapatan asli daerah memiliki kontribusi terbesar dalam penerimaan daerah baik dari pajak daerah dan retribusi daerah. Akan tetapi, terdapat beberapa kendala yang dihadapi pemerintah dalam meningkatkan pendapatan asli daerah dimana masih rendahnya tingkat kepatuhan masyarakat untuk membayar pajak daerah maupun retribusi daerah. Wiriya mengatakan, tidak tercapainya pendapatan asli daerah bisa diakibatkan oleh kurangnya kesadaran masyarakat dalam membayar pajak. Dibuktikan dari Realisasi pendapatan asli daerah provinsi Sumatera Utara menurun dibandingkan triwulan III tahun 2018. Realisasi pendapatan asli daerah pada triwulan III 2019 tercatat 58,0\%, lebih rendah dari periode yang sama tahun lalu sebesar $59,9 \%$ (Tribun, 2019).

Dalam rangka meningkatkan pendapatan asli daerah melalui pemungutan pajak daerah dan retribusi daerah, Upaya-upaya yang perlu dilakukan oleh Pemerintah Daerah antara lain dengan cara sebagai berikut:

1. Menguatkan proses pemungutan upaya yang dicoba dalam menguatkan proses pemungutan, ialah antara lain memesatkan penataan Perda, menukar tarif, khususnya tarif retribusi serta kenaikan SDM.

2. Meningkatkan pengawasan dapat ditingkatkan yaitu dengan melakukan pemeriksaan secara dadakan dan berkala, memperbaiki proses pengawasan, menerapkan sanksi terhadap penunggak pajak dan sanksi terhadap pihak fiskus, serta meningkatkan pembayaran pajak dan pelayanan yang diberikan oleh daerah. 
3. Meningkatkan efisiensi administrasi dan menekan biaya pemungutan Tindakan yang dilakukan oleh daerah yaitu antara lain memperbaiki prosedur administrasi pajak melalui penyederhanaan admnistrasi pajak, meningkatkan efisiensi pemungutan dari setiap jenis pemungutan. Meningkatkan kapasitas penerimaan melalui perencanaan yang lebih baik Hal ini dapat dilakukan dengan meningkatkan koordinasi dengan instansi terkait di daera

4. Memperluas basis penerimaan tindakan yang dilakukan untuk memperluas basis penerimaan yang dapat dipungut oleh daerah, yang dalam perhitungan ekonomi dianggap potensial, antara lain yaitu mengidentifikasi pembayar pajak baru/potensial dan jumlah pembayar pajak, memperbaiki basis data objek, memperbaiki penilaian, menghitung kapasitas penerimaan dari setiap jenis pungutan.

Sumber-sumber penerimaan daerah yang potensial harus digali secara maksimal dengan melakukan hal-hal sebagaimana dijelaskan, namun tentu saja didalam koridor peraturan perundangundangan yang berlaku, termasuk diantaranya ialah pajak daerah dan retribusi daerah yang memang sudah sejak lama menjadi unsur pendapatan asli daerah yang utama.

Di masa otonomi ini diharapkan wilayah menjadi mandiri di dalam pengelolaan kewenangannya yang diisyarati dengan menguatnya kapasitas fiskal ataupun PAD suatu daerah. Sedangkan itu untuk sebagian hal yang bisa jadi masih kekurangan dana, daerah masih diberi dorongan dari Pemerintah Pusat dalam wujud dana perimbangan. Tetapi tujuan dini pelaksanaan otonomi merupakan mewujudkan Kapasitas Fiskal Daerah yang kokoh dalam menunjang terciptanya kemandirian daerah. Sehingga melalui laporan APBD, peneliti ingin mengenali seberapa besar pengaruh pajak wilayah serta retribusi daerah terhadap kenaikan pendapatan asli daerah?

Banyak peneliti terdahulu yang telah melakukan pengujian tentang Pengaruh Pajak Daerah dan Retribusi Daerah terhadap Kemandirian Keuangan Daerah, menurut Harijanto Sabijono, Fadly Nggilu dan Victorina Tirayoh, menunjukkan bahwa secara parsial variabel pajak daerah berpengaruh positif signifikan terhadap kemandirian keuangan daerah, dan variabel retribusi daerah juga berpengaruh positif signifikan tentang kemandirian keuangan daerah.. Kemudian secara simultan variabel pajak daerah dan retribusi daerah berpengaruh positif terhadap kemandirian keuangan daerah.

Penelitian Regina Usman menunjukan bahwa terdapat Pengaruh Pajak Daerah Dan Retribusi Daerah Terhadap Pendapatan Asli Daerah (PAD) (Studi Kasus pada Pemerintah Daerah Kota Bandung periode 2011-2015) hasil analisis menunjukkan bahwa terdapat pengaruh antara pajak daerah dan retribusi daerah terhadap PAD. Hal ini menunjukkan bahwa pajak daerah dan retribusi daerah memberikan sumbangan yang lumayan besar dalam peningkatan pendapatan asli daerah. Dari beberapa penelitian terdahulu, peneliti tertarik untuk melakukan replikasi penelitian di daerah yang berbeda dengan penelitian Regina Usman. Peneliti mengambil sampel Pemerintahan Kabupaten/Kota di Provinsi Sumatera Utara dan melanjutkan tahun periode 2016-2018, dengan membuat variabel yang sama yaitu pajak daerah dan retribusi daerah.

\section{Kerangka Teoritis dan Pengembangan Hiotesis}

\subsection{Pajak Daerah}

Pajak daerah menurut Mardiasmo (2016: 14), ialah iuran wajib yang dibayarkan oleh individu atau perusahaan kepada daerah tanpa manfaat langsung secara proporsional yang bisa dibebankan berdasarkan pada peraturan perundang-undangan yang berlaku dan digunakan untuk mendanai pemerintah daerah serta pembangunan daerah.

Selain itu pemahaman pajak dari perspektif hukum adalah terjadi akibat adanya suatu ikatan yang muncul karena undang-undang yang menyebabkan munculnya kewajiban warga negara untuk menyetorkan sejumlah dana tertentu kepada negara. Dimana negara memiliki kewenangan untuk memaksa dan pajak digunakan untuk mendanai pengelolaan pemerintahan. Hal ini menunjukkan bahwa pajak yang dipungut harus legal, menjamin kepastian hukum baik bagi agen pajak sebagai pemungut ataupun wajib pajak sebagai wajib pajak.

Sedangkan Pajak melalui perspektif ekonomi dinilai dari beralihnya sumber daya dari sektor privat (rakyat) kepada sektor publik (masyarakat). Hal tersebut memberikan gambaran bahwa pajak 
menyebabkan 2 keadaan menjadi berubah, yaitu: (1) Bertambahnya kemampuan keuangan negara dalam penyediaan barang serta jasa publik yang merupakan kebutuhan masyarakat. (2) Berkurangnya kemampuan individu dalam menguasai sumber daya untuk kepentingan penguasaan barang dan jasa.

\subsection{Retribusi Daerah}

Undang-Undang No. 18 tahun 1997 mengenai pajak daerah dan retribusi daerah sebagaimana telah diubah menjadi Undang-Undang No. 34 tahun 2000 dan terakhir menjadi Undang-Undang No. 28 tahun 2009, menjelaskan bahwa retribusi daerah yaitu : "Pembayaran retribusi daerah dilakukan sebagai imbalan atas jasa atau pemberian izin khusus yang diberikan dan/atau diberikan oleh pemerintah daerah untuk kepentingan orang pribadi atau badan usaha. Sedangkan wajib retribusi adalah orang pribadi atau perusahaan yang wajib membayar retribusi, termasuk pemotongan atau pemungutan retribusi, berdasarkan peraturan perundang-undangan yang mengatur tentang retribusi”.

Retribusi daerah memiliki ciri-ciri sebagai berikut : (1) Retribusi dikutip oleh pemerintah daerah (2) Dalam pengutipannya terdapat paksaan secara ekonomis (3) Retribusi dikenakan pada setiap orang atau badan yang menggunakan jasa-jasa yang disiapkan (4) Adanya kontraprestasi yang secara langsung dapat ditunjuk.

\subsection{Pendapatan Asli Daerah}

Bersumber pada Undang-Undang No 33 Tahun 2004 tentang Perimbangan Keuangan Antara Pusat serta Daerah pasal 1 angka 18 tertulis: Pendapatan asli daerah, berikutnya disebut Pendapatan Asli Daerah merupakan pendapatan yang diperoleh daerah yang dipungut berlandaskan peraturan daerah sesuai dengan peraturan perundang- undangan. Sedangkan Menurut Halim:2012 pendapatan asli daerah sebagai semua penerimaan daerah yang berawal dari sumber ekonomi asli daerah. Pendapatan ini bersumber dari empat jenis pemasukan, seperti pajak daerah, retribusi daerah, pengelolaan kekayaan yang dipisah, dan pendapatan sah lain-lain.

Halim (2012:101) menguraikan bahwa kelompok pendapatan asli daerah dipisahkan menjadi 4 tipe pendapatan, yaitu sebagai berikut:

1. Pajak Daerah, yaitu pendapatan daerah yang berasal dari pajak.

2. Retribusi daerah, yaitu pendapatan daerah yang bersumber dari retribusi.

3. Hasil Pengelolaan Kekayaan Milik Daerah yang Dipisahkan Hasil pengelolaan kekayaan milik daerah yang dipisahkan ialah penerimaan daerah yang bersumber dari pengelolaan kekayaan daerah yang dipisahkan.

4. Pendapatan asli daerah lain-lain yang sah ini merupakan penerimaan daerah yang berasal dari lainlain milik pemerintah daerah.

\subsection{Kerangka Berpikir}

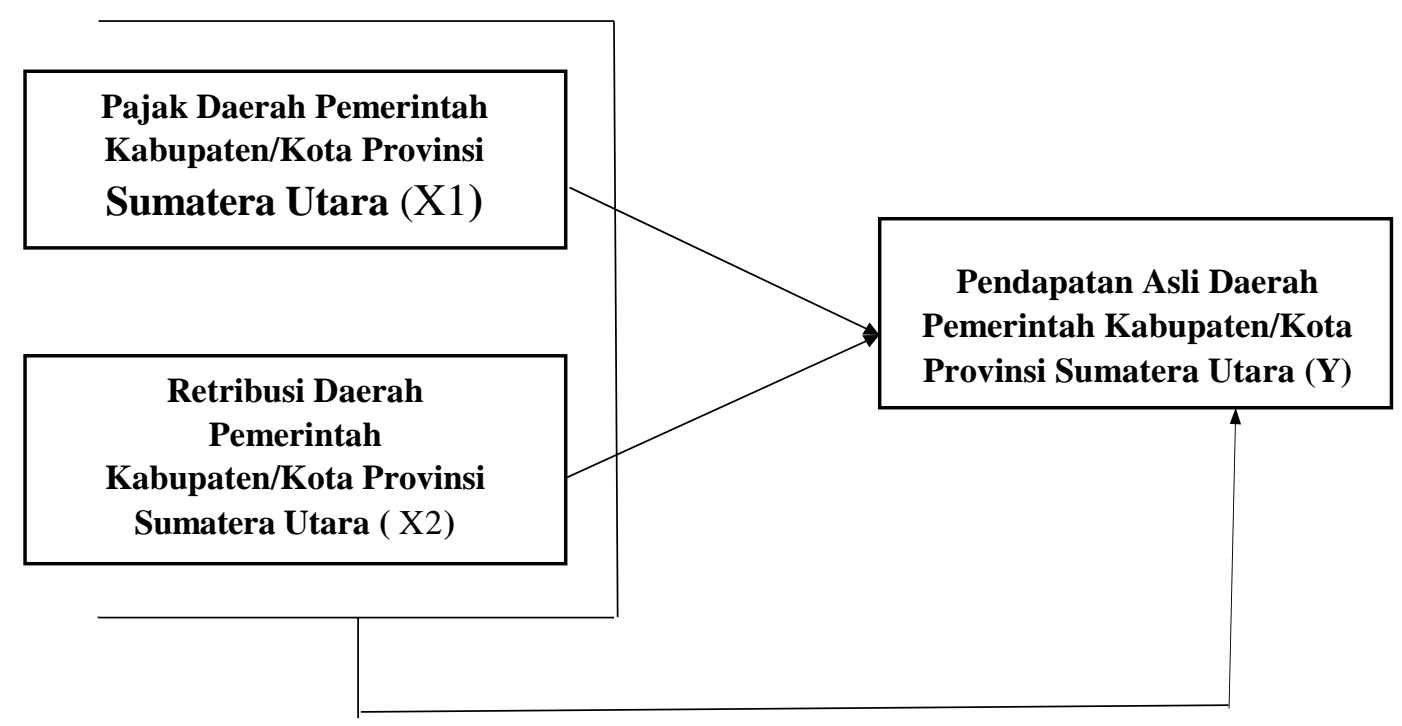

Gambar 2.1 Kerangka Berpikir Jurnal Akuntansi dan Perpajakan Indonesia UNIMED 
Berdasarkan kerangka berpikir ditas, maka hipotesis penelitian ini adalah sebagai berikut:

H1: Penerimaan pajak daerah berpengaruh terhadap peningkatan Pendapatan Asli Daerah Provinsi Sumatera Utara

H2 : Penerimaan retribusi daerah berpengaruh terhadap peningkatan Pendapatan Asli Daerah Provinsi Sumatera utara

H3 : $\quad$ Penerimaan pajak daerah dan retribusi daerah secara bersama-sama berpengaruh terhadap peningkatan Pendapatan Asli Daerah Provinsi Sumatera Utara.

\section{Metode Penelitian}

Penelitian ini dilakukan pada Pemerintahan Kabupaten/Kota di Provinsi Sumatera Utara dengan menggunakan data sekunder yang didapat dengan mengakses data pada situs www.djpk.depkeu.go.id. Populasi pada penelitian ini ialah Pemerintahan Kabupaten/Kota yang ada di Provinsi Sumatera Utara tahun 2017-2020. Teknik pengambilan sampel yang digunakan dalam penelitian ini adalah teknik sampling jenuh. Sampling jenuh merupakan teknik penentuan sampel bila seluruh anggota populasi dipergunakan sebagai sampel. Sampel dalam penelitian ini adalah beberapa Kabupaten/Kota yang ada di Provinsi Sumatera Utara sejumlah 33 Kabupaten/Kota di Provinsi Sumatera Utara.

Analisis data penelitian ini meliputi statistik deskriptif untuk pengujian hipotesis dan pembahasan hasil penelitian. Untuk memberikan gambaran dari faktor-faktor penelitian, yang meliputi realisasi pajak daerah dan retribusi daerah, serta variabel peningkatan pendapatan daerah..

\section{Hasil}

\subsection{Analisis Regresi Berganda}

Beberapa langkah dapat dilakukan untuk mengidentifikasi hubungan antara variabel bebas dan variabel terikat dengan menggunakan regresi linier untuk mengolah data, melalui X1 (Pajak Daerah) dan X2 (Retribusi Daerah) terhadap Y (Pendapatan Asli Daerah).

Tabel 4.1 Hasil regresi

Coefficients $^{\mathrm{a}}$

\begin{tabular}{|ll|r|r|r|}
\hline Model & \multicolumn{2}{|c|}{ Unstandardized Coefficients } & \multicolumn{1}{c|}{$\begin{array}{c}\text { Standardized } \\
\text { Coefficients }\end{array}$} \\
\cline { 3 - 5 } & & \multicolumn{1}{|c|}{ B } & \multicolumn{1}{c|}{ Std. Error } & \multicolumn{1}{c|}{ Beta } \\
\hline \multirow{2}{*}{1} & (Constant) & -143925074939 & 52201736047 & \\
& pajak daerah & 1050631436958 & 132564170003 & .630 \\
& retribusi daerah & -86990565158 & 203782787592 & -.034 \\
\hline
\end{tabular}

Dependent Variable: pad

Sumber : Hasil Pengujian SPSS 2021

Berdasarkan dari table diatas, maka dapat dilihat persamaan regresi yang digunakan dalam penelitian ini adalah:

$Y=-143925074939+1050631436958(P D)-\mathbf{- 8 6 9 9 0 5 6 5 1 5 8}(R D)$

penjelasan:

1. Konstanta sebesar 143925074939 membuktikan bahwa apabila tidak ada variabel independen $(\mathrm{X} 1=0$ dan $\mathrm{X} 2=0)$ maka variabel dependen $(\mathrm{Y})$ sebesar -143925074939 
2. Nilai koefisien regresi dari variabel Pajak Daerah sebesar 1050631436958 membuktikan bahwa setiap kenaikan Pajak Daerah 1\% diikuti oleh kenaikan Pendapatan Asli Daerah 1050631436958 dengan asumsi variabel lainnya sama dengan nol.

3. Nilai koefisien regresi dari variabel Retribusi Daerah sebesar -86990565158 membuktikan bahwa setiap penambahan Pajak Daerah $1 \%$ diikuti oleh penambahan Pendapatan Asli Daerah 0,1050631436958 dengan anggapan bahwa variabel lainnya sama dengan nol..

\subsection{Uji Koefisien Determinasi (R2)}

Koefisien Determinasi (R2) dapat digunakan untuk menilai kemampuan variabel bebas dalam menjelaskan variabel terikat. Koefisien determinasi memiliki nilai antara 0 dan 1 . Nilai (R2) yang kecil berarti kemampuan variabel independen dalam menjelaskan variasi variabel dependen sangat terbatas. Apabila besarnya koefisien determinasi mendekati angka 1, maka variabel independen akan berpengaruh sempurna terhadap variabel dependen.

Tabel 2. Hasil Uji Koefisien Determinasi $\left(\mathrm{R}^{2}\right)$

\begin{tabular}{|l|r|r|r|c|}
\multicolumn{7}{|c|}{ Model Summary $^{\mathbf{b}}$} \\
\hline $\begin{array}{l}\text { Mode } \\
1\end{array}$ & $\mathrm{R}$ & R Square & $\begin{array}{c}\text { Adjusted R } \\
\text { Square }\end{array}$ & $\begin{array}{c}\text { Std. Error of the } \\
\text { Estimate }\end{array}$ \\
\hline 1 & $.635^{\mathrm{a}}$ & .403 & .390 & 226638728337 \\
\hline
\end{tabular}

a. Predictors: (Constant), retribusi daerah, pajak daerah

Dari output diatas, didapatkan nilai Adjusted R2 sebesar 0,390 yang artinya pengaruh variabel independen yaitu Pajak daerah (X1) dan retribusi daerah (X2) terhadap variabel dependen yaitu Pendapatan Asli Daerah (Y) sebesar 39,0 \%, sedangkan sisanya 61,0 \% dijelaskan oleh variabelvariabel lain di luar penelitian ini.

\subsection{Hasil Uji Parsial}

Tabel 3. Hasil Uji Parsial ( Uji T )

\section{Coefficients $^{\mathrm{a}}$}

\begin{tabular}{|l|r|r|}
\hline \multicolumn{1}{|c|}{ Model } & \multicolumn{1}{c|}{ T } & \multicolumn{1}{c|}{ Sig. } \\
\hline 1 (Constant) Pajak & -2.757 & 007 \\
Daerah & 7.925 & 000 \\
Retribusi Daerah & -427 & 670 \\
& & \\
\hline
\end{tabular}

a. Dependent Variable: PAD

\section{Pengaruh Pajak Daerah Terhadap Pendapatan Asli Daerah (PAD)}

Hasil analisis data uji parsial menunjukkan bahwa pengaruh pajak daerah terhadap pendapatan asli daerah berdasarkan hasil pengujian memiliki nilai signifikansi sebesar 0,000 lebih kecil dari $\alpha=0,05$. Dengan demikian hal ini menunjukkan H1 diterima. Artinya Pajak daerah berpengaruh signifikan terhadap Pendapatan Asli Daerah. Artinya setiap terjadi kenaikan suatu pajak daerah akan mempengaruhi naiknya pendapatan asli daerah.

Hasil penelitian menunjukkan bahwa pajak daerah berpengaruh secara signifikan positif. Hasil penelitian ini sama dengan penelitian yang dilakukan oleh Dicki (2018) yang menemukan bahwa pajak daerah berpengaruh positif dan signifikan terhadap Pendapatan Asli Daerah. Berdasarkan penelitian 
Usman (2015) yang menyimpulkan bahwa semakin besar jumlah pajak daerah yang diperoleh maka penerimaan Pendapatan Asil Daerah akan semakin besar. Artinya pajak daerah berpengaruh signifikan terhadap Pendapatan Asli Daerah.

\section{Pengaruh Retribusi Daerah Terhadap Pendapatan Asli Daerah (PAD)}

Pengaruh retribusi daerah terhadap pendapatan asli daera berdasarkan hasil pengujian diperoleh nilai signifikansinya sebesar 0,670 lebih besar dari $\alpha=0,05$. Ini menunjukkan $\mathrm{H} 2$ ditolak. Artinya retribusi daerah tidak berpengaruh signifikan terhadap pendapatan asli daerah Kabupaten/Kota Sumatera Utara tahun 2016- 2018, sehingga besar kecilnya penerimaan retribusi daerah belum tentu berpengaruh terhadap penerimaan pendapatan asli daerah.

Hasil penelitian dari penelitian ini sama dengan hasil dari penelitian yang dilakukan oleh Iqbal dan Sunardika (2015) yang menyebutkan bahwa secara parsial retribusi daerah tidak berpengaruh terhadap peningkatan pendapatan asli daerah di kabupaten Bandung. Penelitian Lakoy (2016) bahwa tidak terdapat pengaruh yang signifikan dari retribusi daerah terhadap pendapatan asli daerah. Berdasarkan penelitian Natoen, Dewata dkk (2018) yang menjelaskan bahwa variabel retribusi daerah tidak berpengaruh signifikan terhadap pendapatan asli daerah (PAD). Oleh sebab itu, hipotesis pada penelitian ini ditolak. Dengan demikian, retribusi pada penelitian ini kurang berkontribusi terhadap pendapatan asli daerah (PAD). Sama dengan penelitian yang dilakukan Zahari (2016), menjelaskan bahwa masih kurangnya akseptabilitas retribusi daerah, yang disebabkan karena pemerintah daerah tidak mampu mengumpulkan uang secara maksimal, sehingga penerimaan retribusi daerah berperan lebih kecil dalam menumbuhkan pendapatan asli daerah.

\subsection{Hasil Uji Simultan}

Tabel 4. Hasil Uji Simultan ( Uji F )

\begin{tabular}{|rl|r|r|r|r|r|}
\hline \multicolumn{2}{|l|}{ Model } & \multicolumn{1}{c|}{$\begin{array}{l}\text { Sum of } \\
\text { Squares }\end{array}$} & df & Mean Square & F & Sig. \\
\hline \multirow{3}{*}{1} & Regression & 332.638 & 2 & 166.319 & 32.380 & $.000^{\mathrm{b}}$ \\
& Residual & 493.105 & 96 & 513.651 & & \\
& Total & 825.743 & 98 & & & \\
\hline
\end{tabular}

a. Dependent Variable: pad

b. Predictors: (Constant), retribusi daerah, pajak daerah

Pada table di atas diperoleh bahwa nilai $U j i F_{\text {hitung }} 32,380$ dengan tingkat probabilitas $(0,000<$ $0,05)$. Derajat bebas pembilang yaitu $\mathrm{k}=2$ sedangkan derajat penyebut yaitu $\mathrm{n}-(\mathrm{k}+1)=99-(2+1)=$ 96. Maka diperoleh nilai $F_{\text {tabel }}$ pada $\alpha=0,05$ adalah 3,09. Karena $F_{\text {hitung }}$ lebih besar daripada $F_{\text {tabel }}$ $(32,380>3,09)$ dan nilai probabilitas sebesar 0,000 lebih kecil dari $\alpha=0,05$ maka dapat disimpulkan $\mathrm{H}_{0}$ ditolak, artinya koefisien regresi linear berganda adalah signifikan. Maka dapat disimpulkan bahwa pajak daerah dan retribusi daerah secara simultan berpengaruh signifikan terhadap pendapatan asli daerah

\section{Kesimpulan dan saran}

\subsection{Kesimpulan}

Tujuan dari penelitian ini adalah untuk mengetahui bagaimana pendapatan pajak daerah dan retribusi daerah mempengaruhi pendapatan asli daerah (PAD). Kesimpulan Setelah melakukan penelitian dan analisis terhadap hasil penelitian, maka dapat di tarik kesimpulan bahwa pajak daerah berpengaruh signifikan terhadap pendapatan asli daerah Kab/Kota Sumatera Utara, retribusi daerah tidak berpengaruh terhadap pendapatan asli daerah Kab/Kota Sumatera Utara dan secara simultan variabel pajak daerah dan retribusi daerah berpengaruh terhadap pendapatan asli daerah (PAD).

\subsection{Saran}


Berdasarkan penjelasan kesimpulan diatas, maka saran yang dapat diberikan peneliti adalah sebagai berikut:

\section{Bagi Pemerintah Daerah Provinsi Sumatera Utara}

Bagi Pemerintah Daerah sebaiknya berkontribusi untuk meningkatkan penerimaan pajak daerah karena dengan meningkatnya penerimaan pajak daerah akan berpengaruh pada peningkatan Pendapatan asli Daerah. Dengan meningkatnya Pendapatan Asli Daerah pemerintah akan semakin mudah membiayai kegiatan-kegiatan dan keperluan daerah yang nantinya akan meningkatkan kinerja pemerintah daerah.

Lebih lanjut, perlu diadakan sosialisasi kepada masyarakat tentang potensi lahan yang dimiliki provinsi sumatera utara diperlukan agar masyarakat luas mengetahui dan investor lebih tertarik untuk menanamkan modalnya.. Contohnya sosialisasi mengenai potensi daerah wisata yang ada di provinsi sumatera utara.

Menurut temuan analisis mengenai retribusi daerah yang tidak signifikan, hal ini sangat berpengaruh bagi penerimaan Pendapatan Asli Daerah di Provinsi Sumatera Utara, maka dari itu dalam pengawasan retribusi daerah harus lebih memperhatikan pengaturan dan pengawasan penerimaan retribusi daerah secara khusus, sehingga kontribusi retribusi daerah dapat bertambah.

\section{Bagi Peneliti Selanjutnya}

Peneliti harus dapat menambah atau mengubah variabel yang ada dengan faktor lain yang mempengaruhi Pendapatan Asli Daerah di masa yang akan datang serta menambah tahun pengamatan sehingga hasil yang di peroleh lebih akurat.

\section{Referensi}

Badan Pusat Statistik Sumut. 2018. Statistik Keuangan Pemerintah Daerah Provinsi Sumatera Utara 2016-2018. Medan: BPS Sumut

Dantes dan Nyoman, 2012. Metode Penelitian. Yogyakarta: Andi

\section{http://www.tribun.com 2019}

Iqbal, Sunardika. 2018. Pengaruh Penerimaan Pajak Daerah dan Retribusi Daerah Terhadap Pendapatan Asli Daerah Kabupaten Bandung. (Studi Kasus Pada Badan Keuangan Daerah Kabupaten Bandung Periode 2009- 2015). Jurnal Ilmiah Akuntansi Universitas Bale Bandung.Vol 9 No. 1 Tahun 2018.

Natoen, Dewatac dkk, 2018. Pengaruh Pajak Daerah dan Retribusi Daerah Terhadap Pendapatan Asli Daerah Provinsi Sumatera Selatan. Jurnal Riset Terapan Akuntansi Politeknik Negeri Sriwijaya. Vol. 2, No. 1 Januari 2018

Nggilu, Sabijono, dan Tirayoh, 2016. Pengaruh Pajak daerah terhadap kemandirian keuangan daerah pada pemerinta kabupaten/kota di provinsi gorontalo. Jurnal Penelitian Universitas Sam Ratulangi Manado Vol 16, No 04, 2016.

Rahmawati Widya Putri, 2016. Analisis Kontribusi Retribusi Parkir Terhadap Pendapatan Asli Daerah Kabupaten Malang. Jurnal Penelitian Universitas Negeri Malang Vol 8, No 1, 2016.

Undang-Undang Republik Indonesia Nomor. 23 Tahun 2014 tentang Pemerintah Daerah.

Undang-Undang Republik Indonesia Nomor 32 Tahun 2004 tentang Pemerintah Daerah.

Undang-Undang Republik Indonesia Nomor 28 Tahun 2009 Tentang Pajak Daerah dan Retribusi Daerah

Undang-Undang Nomor 34 Tahun 2000 tentang Perubahan Atas Undang-Undang Nomor 18 Tahun 1997 tentang Pajak Daerah dan Retribusi Daerah.

Undang-Undang Republik Indonesia Nomor 33 Tahun 2004 Tentang Perimbangan Keuangan Antara Pemerintah Pusat dan Pemerintah Daerah. 
Usman Regina, 2016. Pengaruh pajak daerah dan retribusi daerah terhadap pendapatan asli daerah (PAD) studi kasus pada pemerintah daerah Kota Bandung periode 2011-2015.

www.djpk.kemenkeu.go.id 2019. Pedoman Umum Pajak Daerah dan Retribusi Daerah. Buku Pedoman.

Vanni, K. M., \& Rokhman, W. (2018). Analisis Faktor-Faktor Yang Mempengaruhi Non Performing Financing Pada Perbankan Syariah Di Indonesia Tahun 2011-2016. Equilibrium: Jurnal Ekonomi Syariah, 5(2), 306. https://doi.org/10.21043/equilibrium.v5i2.2776 